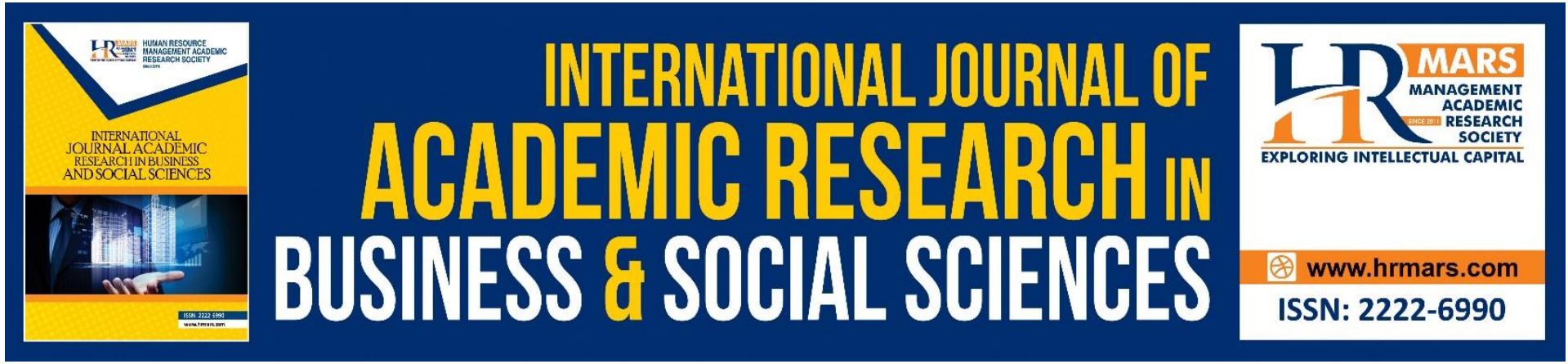

\title{
Transexual Prohibition Factors: The Islam and Medical Perspective
}

Wan Nur Izzati Wan Nor Anas, Abdul Karim Ali, Bahiyah Ahmad, Wan Mohd Khairul Firdaus Wan Khairuldin

To Link this Article: http://dx.doi.org/10.6007/IJARBSS/v11-i7/10394

DOI:10.6007/IJARBSS/v11-i7/10394

Received: 15 May 2021, Revised: 18 June 2021, Accepted: 30 June 2021

Published Online: 06 July 2021

In-Text Citation: (Anas et al., 2021)

To Cite this Article: Anas, W. N. I. W. N., Ali, A. K., Ahmad, B., \& Khairuldin, W. M. K. F. W. (2021). Transexual Prohibition Factors: The Islam and Medical Perspective. International Journal of Academic Research in Business and Social Sciences, 11(7), 1-7.

Copyright: (c) 2021 The Author(s)

Published by Human Resource Management Academic Research Society (www.hrmars.com)

This article is published under the Creative Commons Attribution (CC BY 4.0) license. Anyone may reproduce, distribute, translate and create derivative works of this article (for both commercial and non-commercial purposes), subject to full attribution to the original publication and authors. The full terms of this license may be seen at: http://creativecommons.org/licences/by/4.0/legalcode

Vol. 11, No. 7, 2021, Pg. 1 - 7

Full Terms \& Conditions of access and use can be found at http://hrmars.com/index.php/pages/detail/publication-ethics 


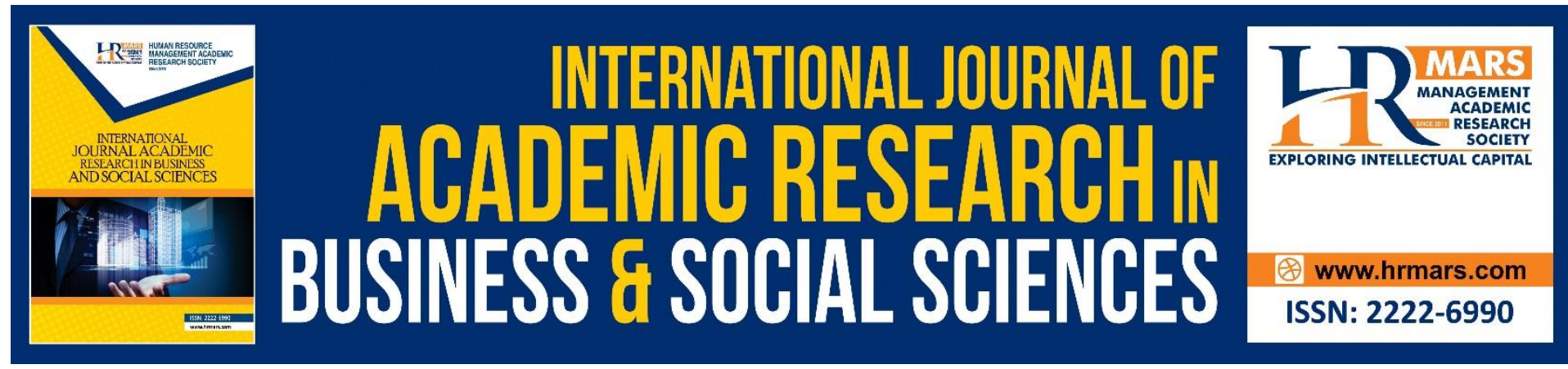

\title{
Transexual Prohibition Factors: The Islam and Medical Perspective
}

\author{
Wan Nur Izzati Wan Nor Anas ${ }^{1}$, Abdul Karim Ali ${ }^{1}$, Bahiyah \\ Ahmad $^{1}$, Wan Mohd Khairul Firdaus Wan Khairuldin ${ }^{2}$ \\ ${ }^{1}$ Department of Figh and Usul Fiqh, Academy of Islamic Studies, Universiti Malaya, Kuala \\ Lumpur, ${ }^{2}$ Fakulty of Islamic Contemporary Studies, Universiti Sultan Zainal Abidin, \\ Terengganu \\ Email: abdkarim@um.edu.my
}

\begin{abstract}
Malaysia is an Islamic country. The majority of people in Malaysia are Malays and Muslims. Recently, social problems such as transgender people have become a concern of society and the country. This is because statistics show that the number of transgender people in the country increases from year to year. It was also a concern when many Malay Muslim nations were slipping into transsexuality. At the same time, Islam is a religion that forbids the similarity of the opposite sex. In addition, several studies found that transgender problems will lead the group to other social problems, such as the practice of reverse sex. This article was written to identify the factors of transgender prohibition based on Islamic law and identify whether gender reassignment through gender reassignment surgery or by using hormone treatment will have a detrimental effect on health. In order to achieve both of these objectives, the documentation method is carried out. A documentation study was conducted to obtain data related to transgender in Malaysia. The data collected used content analysis to explain. This study found that there are three main factors of transgender prohibition based on Islamic law. First, the transformation of God's creation. Second, the similarity of different sexes (tasyabbuh) and third harm. Meanwhile, gender reassignment by transgender people through gender reassignment surgery or using hormone treatment will have a detrimental effect on health.
\end{abstract}

Keywords: Factors, Transsexual, Islamic Law, Medical.

\section{Introduction}

The creation of human beings that no one can deny is that beings are created with only two sexes: male and female. However, for those who have two genitals at birth (khunsa), their gender will be identified in several ways that have been outlined by Islam and medicine (Sajuri, 2006).

Transsexuals have several definitions of their own. According to Stryker (2008), transgender individuals are those who have a desire to be of a different gender to themselves. Sometimes, their desires are manifested through gender reassignment surgery and hormone treatment. 
However, these methods make the group totally or entirely different genders (Yahaya \& Ramli, 2007). Therefore, transsexual people refer to people who resemble the opposite sex, including undergoing gender reassignment surgery and using hormone treatment.

The problem of transsexualism is a big problem and issue in Islam. This is because transsexual behavior is against the nature of human creation and challenges the provisions of Allah S.W.T. Therefore, this has been clearly forbidden by Islam based on the Quran, hadith and ijma' (Haridi, Rahman \& Wazir, 2016).

\section{Transsexual Prohibition Factors in Islam}

There are several factors that prohibit transsexualism in Islam.

\section{Transformation of the creation of Allah SWT}

Some transgender people change their sexual anatomy through surgery and hormone treatment to achieve their desire to resemble the opposite sex as a whole. However, it is clear that anatomical alterations include alterations of God's creation SWT based on surah a-nisa 'verse 119 which means:

Translation: (Satan) says: I will certainly mislead them and delude them with empty hopes. Also, I will order them and they will slit the ears of cattle1 and alter Allah's creation. "And whoever takes Satan as a guardian instead of Allah has certainly suffered a tremendous loss.". (al-Nisa 4: 119).

Several commentators give views related to this verse and can raise several things.

i. Changing the creation of Allah SWT means changing the religion of Allah SWT.

ii. To change the creation of Allah SWT is to cut the genitals (Castration). Even so, it is haram if the castration is done to human beings. However, there are differences of opinion when it comes to animal affairs. On the other hand, castration against an animal is a must if the act is done based on beneficial reasons.

iii. Changing the creation is drawing a tattoo on the part of the body.

iv. The fourth view is to change Allah SWT's law by forbidding something allowed by Islam and legalizing something that Islam forbids.

v. Associating Allah SWT by worshiping statues, sun, moon and etc.

Al-Tabari has chosen the first view as the strongest view. However, the second view to the fifth view can be combined, which also means changing the creation that Allah SWT forbids. Moreover, the word al-Batk mentioned in the verse that carries the meaning of animals' ears is cut off. Therefore, al-Batk is included in changing the creation of Allah SWT in a visible way (Al-Tabari, 2003),

While Ibn Qayyim al-Jawziyyah chose to combine all the views mentioned. In his view, the alteration of the creation is divided into two, namely the first, changing internally, and the second, changing physically. This view of Ibn Qayyim al-Jawziyyah was followed by Sheikh Muhammad Abu Zahrah, who believed that the alteration of the creation is to include the alteration in terms of internal and physical (Abu-Zahrah, 1987). 
There are several hadiths related to changing the creation of Allah SWT.

Translation: From 'Aishah RA, a female slave from among the Ansar got married and fell ill until her hair fell. They (her family) wanted to connect the hair of the female slave, so they asked the Prophet saw. He said: Allah SWT curses the woman who connects her hair and the family who asks for her hair to be connected.

In addition, there is also a hadith narrated by Ibn 'Umar RA in connection with the alteration of the creation of Allah SWT:

Translation: From Ibn 'Umar RA that the Prophet saw said: Allah SWT curses the woman who connects her hair, the woman who asks for her hair to be tied, the woman who cuts the tattoo, and the woman who asks to have the tattoo cut.

Moreover, there is another hadith related to the curse of Allah S.W.T on those who alter His creation.

Translation: From Ibn Mas'ud RA he said: Allah SWT curses the woman who cuts tattoos, the woman who asks to be tattooed, the woman who shaves her eyebrows, and the woman who spreads her teeth for beauty (all of them) are the ones who change the creation of Allah S.W.T. Why do I not curse the person whom the Prophet has cursed SAW when it has been mentioned in the book of Allah S.W.T: And whatever command brought by the Messenger of Allah (s.a.w) to you then accept and practice, and whatever He forbids you to do then obey His prohibition.

Based on these three hadiths shows that the prohibition of changing the creation of Allah SWT. Everything that alters the creation of Allah SWT is haram and forbidden altogether (Ibn 'Abd al-Barr, 1981).

In transsexuals, some transsexual situations are changing their physical condition to look like the gender they want i.e., a different gender from themselves. The change forms include using hormone treatments, doing gender reassignment, shaving eyebrows, connecting hair, etc. Of course, these forms of alteration are illegal because they have altered the creation of Allah S.W.T.

\section{Similarity of the Different Gender (Tasyabbuh)}

Islam is a religion that forbids its adherents to resemble the other sex in terms of dress, way of speaking, walking, and so on (Shamsuddin, 2016).

Translation: From Ibn Abbas, he said: The Prophet (peace and blessings of Allaah be upon him) cursed men who resembled women and women who resembled men.

In addition, other hadiths talk about this matter.

Translation: "From Yahya, From Ikrimah, From Ibn Abbas R.A .: Rasulullah SAW has cursed men who resemble women and people who resemble men from among women. Get them 
out of your houses. Ibn 'Abbas added:" So the Prophet s.a.w removed the man, and Umar also removed the man. "

Based on the above hadith, the resemblance of individuals with different genders is unlawful. The word al-mukhannath is a man who resembles a woman and the word zadalah refers to a woman who resembles a man (Ibn al-Athir, 1979). According to al-San'ani, the hadith also uses the word curse to show that the act of resembling the other sex is a great sin (Ismail, 1971). Al-Shaukani also makes this hadith as a prohibition in the imitation of the other sex in terms of speech, behavior, dress and so on (Al-Shaukani, 1993).

Al-Tabari says that men cannot resemble women or vice versa. In fact, this view is added when Ibn Hajar details the unauthorized similarities, including speaking, walking, and wearing (AlMakhfuri, 2003).

While there are also transsexuals who do not change their limbs and just act like a different gender to themselves, such as the way they dress, the way they walk, etc. Thus, transgender laws remain illegal based on them resembling the other sex.

\section{Harm}

Transgender problems lead to harm to transsexual people themselves as well as society and the country. Transsexuals are more likely to have problems during gender reassignment surgery, such as venous platelets. In addition, society becomes confused with each other regarding a person's original gender. This is because those involved with transsexual symptoms will become obsessed with changing their identity as a whole. Change of identity not only by performing genital surgery or injecting hormones will also change all identity identification, such as applying for a change of gender stated in the identity card (Sajuri, 2006). This confusion will affect matters involving Islamic law such as marriage, inheritance, worship and death. According to Lee (2012), the effect of transsexual symptoms on society is to damage the social system and society.

Transgender problems are also behaviors that adversely affect the country at the expense of the country's oriental values. These transsexual symptoms will lead to the emergence of HIV disease and this becomes a liability to the state to bear their medical costs (Lee, 2012).

Therefore, it is clear that based on the method of fiqh that the harm must be eliminated, then transsexuals must also be eliminated (Al-Suyuti, 1990). This method also covers unprecedented harm utilizing obstruction and restraint. In contrast, the harm that has occurred is eliminated in various ways allowed by Islamic law so that the effect does not become greater (Al-Suyuti, 1990).

\section{Transsexual Effects on Medical Perspective}

Transsexuals have something to do with medicine and health. This is because there are among them transsexuals who decide to change their limbs by undergoing gender reassignment surgery or using hormone treatment. Both of these methods involve medicine that has an impact on health. 
In medicine, gender reassignment is divided into two. First, the transformation of the limb from the original form to the form of the other sex. Second, genital alteration. For male to female transsexuals, they will usually perform breast augmentation using implants. Although the method used is the same for women who want large breasts, the anatomy is different because the original gender of male to female transsexuals is male. Normally, male to female transsexual breasts are not significant and may lack lipomatous tissue (Kanhaj, 1999)

In general, these transsexual behaviors involve behaviors that are contrary to the nature of human creation. This can be seen when an individual who is quite perfect in creating a normal human being changes his or her gender through gender reassignment surgery or hormone treatment. This behavior is against human nature, and it has a bad effect and harm on oneself and society (Halim, 2017). Gender surgery leads to harm that results in such complications (Al-Zuhaili, 1997). First, bleeding or hematoma. Second, recto-vaginal fistula wound healing is the hole developed between the column and the vagina. Third, pulmonary thromboembolism. Fourth, partial or complete necrosis of the flap. Fifth, intravaginal hair growth, and sixth, hypertrophic fear.

Gender surgery is at risk for venous platelets, pulmonary embolism, and even death. Venous platelets occur when there is a blood clot in a vein. While pulmonary vein embolism is the occurrence of blood clots in the pulmonary arteries (Bowman \& Goldberg, 2006).

In addition, gender reassignment surgery can also cause changes in urination habits that cause discomfort to transsexuals. In addition, the effects of gender reassignment surgery will result in the emergence of an instinct to love someone of the same gender as oneself. Such instincts can change aggressively by including having same-sex intercourse (Kumarashwaran Vadevelu, 2016). Same-sex intercourse will cause diseases such as HIV (Kumarashwaran Vadevelu, 2016). Transgender problems are often associated with homosexual and lesbian problems (Musa, 2005). In October 2017, it was reported that 65 percent of HIV -positive people were (LGBT). This percentage was reported by the Senior Principal Assistant Director (HIV/STI) in the Kuala Lumpur and Putrajaya Health Department (Jamhari, 2017).

In addition to getting diseases such as HIV, people with identity crisis problems, including transsexuals, have a high risk of using drugs (Ministry of Health Malaysia, 2017). They use drugs and medications like steroids, birth control pills. They also use illicit drugs to change their body parts, such as removing body hair and enlarging breasts. Typically, they use drugs such as heroin, stimulants, alcohol and marijuana. In addition, the effects of taking hormone medications will cause vomiting, breast pain, migraines, etc (Ministry of Health Malaysia, 2017).

\section{Conclusion}

Ultimately, Islam does not recognize transsexual acts. This is clearly contained in the Qur'an and sunnah. The procedure is also supported from a health and medical perspective which also has a negative impact on the human body. Neglect of this prohibition has caused the community to be in a state of chaos, especially from the aspect of socialization. 


\section{References}

Abu-Zahrah, M. (1987). Zahrah al-Tafasir. Kaherah: Dar al-Fikr al- 'Arabi.

Al-Husni, M. I. (1971). Subul al-Salam. Beirut: Dar al-Kutub al-Ilmiyyah.

Al-Jawziyyah, I. Q. (1427H), Badai'al-Tafsir: al-Jami' lima Fassarahu al-Imam IbnQayyim alJawiziyyah, Al-Dammam: Dar Ibn al-Jawzi.

Al-Mubarakfuri, M. A. R. (2003). Tuhfah al-Ahwazi. Beirut: Dar al-Fikr.

Al-Shaukani, M. A. (1993). Nayl al-Awtar. Mesir: Dar al-Tiba'ah al-Muniriyyah.

Al-Suyuti, J. (1990). Al-Ashbah wa al-Nazair fi Figh al- Shafi'iyyah. Beirut, Dar al-Kutub al'Ilmiyyah.

Al-Tabari, M. J. (2003), Tafsir al-Tabari: Jami' al-Bayan 'an Ta'wil al-Qur'an, Kaherah: Dar Hajar ,Jil7.

Al-Zuhaili, W. (1997). al-Figh al-Islami wa Adillatuh. Beirut: Dar al-Fikr,1997.

Anas, W. N. I. W. N., Daud, N., Khairul, W. M., \& Khairuldin, F. W. (2017). The Stance of Alimony or Maintenance for Working Wives within Working Period: An Analysis from the Qualified Jurists (Muftis). International Journal of Academic Research in Business and Social Sciences, 7(4), 2222-6990.

Bowman, C., \& Goldberg, J. (2006). "Care of the Patient Undergoing Sex Reassignment Sugery. Vancouver Coastal Health", Transcend Transgender Support \& Education Society, and the Canadian Rainbow Health Coalition 2006(12).

Embong, A. H., Khairuldin, W. M. K. F. W., Yasin, M. F. M., Hassan, A., \& Ibrahim, M. S. (2021). Between Reformist and Interpretation: Notes on Hamka's Methodological Strategies as Reformist Mufassir. In First International Conference on Science, Technology, Engineering and Industrial Revolution (ICSTEIR 2020) (pp. 415-422). Atlantis Press.

Hassan, S. A., \& Khairuldin, W. M. K. F. W. (2020). Research Design Based on Fatwa Making Process: An Exploratory Study. International Journal of Higher Education 9 (6), 241-246

IBN-al-Athir, M. D. (1979). al-Nihayah fi al-Gharib al-Hadith wa al-Athar. Damsyik: Dar al-Fikr.

Kanhai, R. C. J., Hage, J. J., Asscheman, H., \& Mulder, J. W. (1999). "Augmentation mammaplasty in maleto-female transsexuals", Plastic and Reconstructive Surgery. 104 (1999), 542-549.

Majid, S. F., Khairuldin, W. M. K. F., \& Ajmain, M. T. (2019). Fiqh Boycott On LGBT Community: A Review. Perdana: International Journal of Academic Research, 6(2), 35-49.

Penyelidikan Islam, 19 (2006).

Sajuri, N. (2006). "Pertukaran status jantina dalam mykad dan implikasinya”, Jurnal Shamsuddin, M. M. (2016). "Pengubahan Semula Jantina Bagi Transeksual Mengikut Sudut Pandang Fiqh", Journal of Education and Social Science. 5(2016). 